Nordisk Tidsskrift for Kriminalvidenskab 2000

\title{
STYRING VED STRAFF ${ }^{1}$
}

\section{Av PROFESSOR NILS CHRISTIE}

This article contains a discussion of the upper and lower limits for the use of punishment in societies of our type. There are usually two positions confronting each other: the minimalist and the maximalist. Minimalists tend to take their point of departure in deplorable acts, and then ask how these acts should be addressed. Maximalists begin at a later point in the chain of definition. To them, crime exists as a given entity, and punishment follows as a natural consequence.

The author's position is a minimalist one. The use of punishment must be evaluated according to the total set of values we want to preserve in society. Punishment may preserve certain core values, but at the same time punishment represents an attack on other core values. A central problem in modern states is that the expansion of the penal apparatus threatens the civil society. This expansion should be limited. Civil solutions based on compensation and forgiveness should be encouraged and made available in all cases, - regardless of how serious they are. *

\section{Ærede forsamling}

Jeg vil benytte denne anledning, med så mye kyndig folk i salen, til å drøfte spørsmålet om de øvre og nedre grenser for et samfunns bruk av straff. Går det an å etablere kriterier for maksimum, for når nok er nok? $\mathrm{Og}$ omvendt, finnes det noen nedre grenser, finnes det et minimum av formell straffanvendelse som et fungerende samfunn av vår type ikke bør gå under?

Det er gjerne to fløyer som står mot hverandre. Det er den fløy som kjemper for mindre bruk av straff, eller mildere straffer om straff skal brukes. Minimalistene vil jeg kalle dem. Og det er deres motpol, maksimalistene, som krever mer og strengere straff for flere typer handlinger.

\section{Minimalistene}

Minimalistene finnes i to utgaver. Lengst går abolisjonistene. Louk Hulsmann, strafferettsprofessor fra Holland, er et representativt eksempel. Han vil avskaffe, ikke bare fengslene, men hele strafferettsinstitusjonen. Han er den ledende kraft i en organisasjon som hver år arrangerer hva de kaller "Conference on Penal Abolition", den siste ble i mai dette år holdt $\mathrm{i}$ Toronto med flere hundre deltakere. Selve navnet, "abolitionism", er en arv fra kampen mot slaveriet, spesielt i USA. Innen den bevegelsen stod kampen mellom dem som på forskjellige vis

\footnotetext{
' Noe utvidet utgave av foredrag holdt på det nordiske kriminalistmøte i Oslo 5 juni 2000.

* Title in English: Controlling Behaviour through Punishment. Orginal in Norwegian.
} 
ville begrense slaveriet, og dem som gikk inn for full avskaffelse. Louk Hulsmanns syn er at konflikter i hovedsak bør løses på sivilt vis, ved møter mellom partene, ved gjenopprettelse av skader, og - hvor tvang må anvendes, ved at slike saker går til de sivile domstoler.

Men som ved kampen om slaveriet, finnes en mer moderat fløy også innen denne bevegelse. Minimalister er et godt navn på disse. Den gamle justisminister i Sverige, Lennart Geijer, mente 500 fanger måtte være tilstrekkelig... Resten måtte kunne ivaretas ved betingede dommer, bøter, erstatning, o.s.v. Geijer var en klar minimalist.

\section{Maksimalistene}

Når det gjelder den annen fløy, har jeg ikke vært i stand til å finne konkrete eksempler på maksimumangivelse. Det nærmeste jeg er kommet slike, var under et møte ved den skotske Kriminalistforening. Jeg var invitert som innleder om fangetall i den industrialiserte verden. Motinnleder var professor James Q.Wilson, en snill og elskverdig mann, og samtidig den sentrale pådriver bakom den enorme vekst i USAs fangetall. Da vi møttes hadde de i USA ca 600 fanger per 100000 innbyggere, altså det tidobbelte av våre fangetall i Norden. Storbritannia hadde dengang ca 110 per 100 000. Uten å nøle sa Wilson til britene; dere må hurtig se til å få opp fangetallet til vårt nivå om dere skal unngå å komme opp i våre problem. Storbritannia burde altså mer enn femdoble fangetallet. $\mathrm{De}$ har senere gjort så godt de har kunnet, nå er de oppe i 125 fanger pr.100 000 . Men USA er uslåelig, de har i samme periode gått opp fra ca 600 til 706 og har nå to millioner fanger. Russland ligger like etter med en million fanger, eller 685 per 100000 innbyggere. Norden ligger som kjent på et nivå med mellom 65 og 75 fanger per 100000 innbyggere

Men hvorfor ikke enda flere? Hvorfor bare to millioner i USA, hvorfor ikke seks? Hvorfor ikke enda flere i Maxi-Maxi isolat, disse blir stadig billigere. Det er personalet som koster, og mennesker trengs snart ikke mer $i$ anstalter med dusj og do på cellen og inngitret luftebalkong utenfor, alt sammen elektronisk styrt og overvåket fra kontrollsentralen. Som Zigmunt Bauman sier i siste nummer av British Journal of Criminology: "Apart from the fact that the prisoners are still eating and defecating, their cells could be mistaken for coffins" (Bauman 2000, s.209). Og videre, hvorfor skal bare halvparten av svart storbyungdom stå under strafferettslig kontroll? Hvorfor ikke de fleste? Hvorfor skal bare løslatte etter sedelighetslovbrudd mot barn få operert inn eller låst fast sendere som til enhver tid forteller myndighetene på ti-meteren hvor de befinner seg? Hvorfor ikke alle sedelighetslovbrytere, eller alle som løslates fra fengsel? Teknikken finnes. Det er den samme som brukes for å peile inn drosjene i Oslo. Straffevolumet øker uten at noen har vedtatt at det skal skje. For maksimalistene går utviklingen deres vei. 


\section{Interessen for grensesetting}

Minimalistene har sine klare ytterpunkt; ingen eller et lite minimum skal straffes. Hos maksimalistene finner vi ikke lignende klare angivelser. Forskjellen henger trolig sammen med grunnleggende forskjeller i synet på kriminalitet. Minimalistene tar sitt utgangspunkt i uønskede handlinger, og spør: Hvordan kan disse handlinger møtes? Ved at noen sier unnskyld, ved tilgivelse, ved erstatning, - eller kan det akkurat her være behov for straff? Handlinger er ikke, men blir. De får forskjellig mening, alt etter den ramme de settes inn i. Ungdommen kan refses av læreren, da blir det en ulydighet han refses for. Men politiet kan tilkalles for samme gjerning, da konverteres ulydigheten til et lovbrudd (Estrada 1999). Maksimalistene tar $i$ større grad sitt utgangspunkt på et senere punkt $i$ definisjonskjeden. Handlinger er, kriminaliteten finnes, straffen fremstår som en naturgitt følge av lovbruddet, og det blir uinteressant å diskutere yttergrensene for straffevolum. Fangetall blir skjebne bestemt av krefter utenfor straffemyndighetenes område. Dette syn er selvfølgelig velegnet til å opprettholde strafferettsinstitusjonens hegemoni. Tar man utgangspunkt $i$ at lovbrudd er skjedd, vil alt annet enn straff kunne sees som unntak, som alternativ i behov av særskilt begrunnelse. Det naturlige svar blir straff. Men tar man utgangspunkt lenger bak i forståelseskjeden - tar man utgangspunkt i den uønskede handling - da blir straffen en av flere sideordnede muligheter. Straffen mister sin hegemoniske posisjon. Jeg kommer snart tilbake til dette resonnement.

\section{Kriterier for vurdering av straffens grenser}

De vanlige argumenter om straff dreier seg om straffens nytte. Virkninger på gjerningsperson og virkninger på potensielle gjerningspersoner. Av og til tas opp de videre nyttehensyn som ivaretagelse av samfunnsånd og gjenopprettelse av verdiene. Kan et samfunn fortsette som samfunn uten at verdiene gjenopprettes ved at verdikrenkere møtes med den tilsiktede pine?

Dette er de vanlige temaer for drøftelser. Men ved å holde oss her mister vi det som for meg står som hovedsaken: Det strafferettslige systemet må først og fremst vurderes ut fra hvordan det harmonerer med et bredt spekter av sentrale målsetninger for hvorledes vi vil ha det $\mathrm{i}$ våre land. Straffen er i seg selv en verdimanifestasjon. Et lands strafferett kan og må ikke først og fremst vurderes ut fra nyttehensyn. Kriminalpolitikken gir viktige signaler om hvilken samfunnstype vi har, samtidig som prinsippene fra kriminalpolitikken påvirker ordningen i de øvrige hovedinstitusjonene i samfunnet. I spennet mellom mini-løsninger og maxi-løsninger kan vi formulere spørsmålet slik: Finner vi det ønskelig eller i det minste akseptabel - å leve i samfunn med sterke sivile preg hvor strafferettsapparatet spiller en relativt beskjeden rolle? Eller finner vi det akseptabelt eller til og med ønskelig å gå inn i en samfunnsform hvor straff har det samme omfang og lignende vide oppgaver som i Russland og i USA; - land som i betydelig grad styrer sine underklasser ved hjelp av strafferettsvesenet? For Nordens 
vedkommende blir spørsmålet om slik styring kan kombineres med vår samfunnsform.

\section{Det inklusive samfunn}

Rune Slagstad har skrevet en bok om De nasjonale strateger (1998). Her siterer han Halvdan Koht, norsk utenriksminister, men viktigst i vår sammenheng; historiker og identitetsskaper. I Kohts (og Slagstads) syn har nasjonsbyggingen i vårt land vært en lang prosess hvor klassepatriotismen er omformet til nasjonalpatriotisme. "..kvar gong ei ny klasse reiste seg og kravde rom og rett og makt $i$ samfunnet, da kunne det med det same sjå ut som at det voks opp hat og såddes frø til ein strid som kunne sprenge heile samfunnet. Men til slutt, når underklassene nådde fram, da synte det seg at samfunnet hadde vida seg ut og vorti mykje rikare enn det før var." (s.456).

Vi er nok her ved kjernen til det som gjør at jeg selv, og mange med meg, arbeider for å begrense styring med straff. Uansett retorikk, lar det seg ikke lenger benekte at det ledende land $\mathrm{i}$ vår kulturkrets, ledende når det gjelder økonomisk, militær og ideologisk kraft, i den strafferettslige sektor - selve maktens kjerneområde - utvikler seg i en retning som står i skjærende kontrast til idealene om det inkluderende demokratiske samfunn. Det sentrale spørsmål for oss her i Norden blir om USA-utviklingen er uunngåelig. Er den strafferettslige utvikling i USA en konsekvens av det økonomiske system? Og er dette en konsekvens vi etter hvert også vil møte her hjemme når det etter USA-modell skjer ytterligere frislipp av økonomien? Et frislipp vi må regne med vil føre til ytterligere øking i klasseforskjellene og ytterligere generell usikkerhet i befolkningen? Vi ser i en rekke industrinasjoner hvordan kriminalpolitikken avprofesjonaliseres, arenaen overtas av politikere. Fratatt styringen av den internasjonale $ø$ konomi øker behovet for andre arenaer, og intet er da mer nærliggende enn styring av den avregulerte økonomis konsekvenser. Usikkerhet, hyppige skifter og utstøting av de minst egnede preger det avregulerte arbeidsmarked. Usikkerheten dulmes ved politikerløfter om hårde tak mot lovovertrederne, et ord som etter hvert blir en eufemisme for underklassen, en betegnelse som i sin tur kan bli en eufemisme for de farlige klasser. Ved disse transformasjoner legges forholdene til rette for krigslignende tilstander. Dere hjalp oss til å vinne krigen mot den ytre fiende, sa USA's justisminister for en tid siden til en gruppe militære eksperter. Og hun fortsatte: Nå må dere hjelpe oss til å vinne krigen mot kriminaliteten her hjemme.

Enhver får feie for sin egen institusjon. Selv om drivkraften skulle ligge i den økonomiske sektor, selv om presset mot internering av flere og for lengere tid skulle komme fra endringene i økonomien, må vi som har lovbruddsektoren som vårt særlige arbeidsområde gjøre to ting. Vi må forsøke å stille diagnosen, analysere hvor presset kommer fra, og hvorfor. Og vi må - om vi har som ideal å bevare hovedtrekkene i vår nåværende samfunnsform - forsøke å dempe veksten 
i den strafferettslige sektor, en vekst som gjør seg gjeldende i nesten alle industrinasjoner. Det gjør at slike som deler det syn jeg her har redegjort for, vil gjøre sitt ytterste for at den strafferettslige sektor i omfang skal holde seg i nærheten av den minimalistiske grense. Det kan, med betydelig rett, hevdes at dette er et verdikonservativt standpunkt.

\section{Bevaring av den sivile sektor}

Formulert på en annen måte, blir det et spørsmål om den sivil sektors omfang $\mathrm{i}$ våre land, sett i forhold til den sektor som representeres av statsapparatets direkte maktutøvelse.

På lovbrudd følger straff, det er hovedregelen i ethvert samfunn, det er slik maksimalistene ser det. Men slik er det jo slett ikke. Samfunn uten sterk statsmakt anvender i stor grad gjenopprettelse eller erstatning for å løse konflikter. Straff ville i slike samfunn være innledning til borgerkrig. De beste grunner taler derfor i slike samfunn i retning av å gi konfliktene den mening at de skal kunne løses, eventuelt stabiliseres, ved sivile tiltak. Men nøyaktig i samme situasjon er moderne storbedrifter. Det er klart at bedriftene ved siden av samarbeid også er i hyppige konflikter med andre bedrifter. Noen av disse konfliktene kunne blitt sett på - gitt den mening - at de var brudd på straffeloven, f.eks. bedrageri eller utpresning. Men økonomiske organisasjoner nøler med å styre andre økonomiske organisasjoner ved bruk av straff. Nettopp i vår globale økonomi lever bedriftene uten noen sterk statsdannelse over seg. De er i analog situasjon til landsbyboere langt fra sentralmyndighetenes rekkevidde. De globale bedrifter henger sammen i en global landsby, straff betyr begynnende krig. Framfor krig har de mer å vinne på forhandlinger og muligheter for senere å gjenoppta samarbeid. De griper til voldgift eller andre mekanismer for gjenopprettelse og fredsskaping. De tar selv hånd om sine konflikter.

Slik gjør de seg i mellom. Men ikke overfor enkeltindivider som kunne plage dem, f.eks. kunder som tar noe fra dem uten å betale. Her er lite å tape og mye å vinne på en politianmeldelse. Men så må jo den moderne stat tenke seg om, og det har staten gjort. Et stykke på vei. Vi har i Norge fått en lov om konfliktråd, påtalemyndigheten oversender straffesaker til et organ skapt for konfliktløsning. Om saken der finner sin løsning, bortfaller strafferettsmyndighetenes befatning med saken. Dette skjer foreløpig bare i de små saker. Men hvorfor bare i det små?

\section{Hvem eier konfliktene?}

Spørsmålet fører oss rett inn i et grunnleggende spørsmål: Hvem eier konfliktene? I følge lov om konfliktråd er det Riksadvokaten som bestemmer hvilke saker som kan gå til konfliktråd. I flere rundskriv angis hvilke saker som kan tas ut av straffesystemet og avgjøres i konfliktråd. 7000 saker havnet siste år hos Konfliktrådene, de fleste oversendt fra politiet. Svært mange gjaldt ungdom 
under den kriminelle lavalder, om konfliktrådene ikke fantes, var det ikke blitt noen sak (cf. Dullum 1998). Men noen gjaldt også eldre personer, og blant disse igjen noen som ellers ville endt med reell straff. Men bare noen. Og et fragment av alle. Hovedregelen er at bare småsaker går i konfliktråd.

Så da, på ny, hvem eier konfliktene? Er de påtalemyndighetens? Eller tilhører de det sivile samfunn? Hvilken logikk, og etikk, tilsier at alvorlige voldsforbrytelser skal straffes, hvis partene seg i mellom klarer å stifte fred? Du mistet ditt øye, men jeg gir deg mitt hus. Du skadet meg ved din vanvittige bilkjøring. Jeg har tilgitt deg.

\section{Den nedre grense}

Finnes det da ingen grenser for handlinger som kan gis til partenes egen avgjørelse om de skulle klare å få slutt på konflikten uten at staten grep inn med straff? Norge rystes mens dette skrives av drapene på to små jenter som var på badetur i Kristiansand-området. Ville det kunne aksepteres at foreldrene sa: Du drepte våre barn. Vi har, etter alt vi har fått å vite, om fortid og også om det vi vet blir din fremtid, tilgitt deg. Og så skjedde det ikke mer med personen eller personene. Jeg er personlig ikke i tvil om at dette ville være den etisk mest høyverdige løsning. Men jeg er heller ikke i tvil om at det er helt urimelig å vente, enn si forlange, at nærstående til de drepte skulle være med på en meglingsprosess som muligens skulle føre fram til et slikt sluttresultat. Det er helt forståelig og moralsk klanderfritt om de nærstående vil ha straff. De har til overmål intet valg etter dagens ordning.

Sebastian Scheerer mener i en artikkel om "Kritik der strafenden Vernuft" (Scheerer 2001) at det finnes et kjerneområde hvor vi ikke kan gi opp straff. Men han vil være gjerrig i bruken. Straffen bør bare anvendes innen det avgrensede område som gjelder den symbolske markering av det Scheerer kaller "menneskets frihetsrom" og bare når det ikke finnes alternative måter å foreta denne markering på. Men selv med disse begrensninger gjenstår ett problem: Straff er den tilsiktede pine. Kan pine gis fortrinn som middel til gjenopprettelse av en verdi som er krenket, fortrinn framfor markering av verdiens betydning ved forsoning, gjenopprettelse og rituelt uttrykt tilgivelse? Enklest er dilemmaet å se ved dødsstraff: Vi dreper deg for å markere at det er galt å drepe. Eller vi sperrer deg inne for livet for å markere hvor galt det var at du ved skadepåførelse tok bort deler av en annens liv. Straffen, den tilsiktede ondepåførelse, blir i seg selv et brudd med de grunnleggende verdier.

\section{Folkets dom?}

Men folket ville ikke godta restriksjoner på straffen, sier påtalemyndigheten.

Her vil jeg stoppe opp og spørre; hvilket folk? Hvis offeret vil tilgi, eller satse på erstatning framfor straff $i$ et sivilt preget oppgjør, er det ikke da trolig at også offerets omgivelse ville godta dette? Og den videre krets, vet vi noe om deres 
hat? To barn drepte for en tid siden et tredje barn et sted i Norge. Moren til den drepte ba innstendig om at de to ikke måtte skades. Så vidt jeg vet har det ikke vært noen inngrep mot dem, de har fortsatt sine liv som barn. En lignende sak i England, men her med litt eldre barn, endte i en fortelling med barn som mordere. De to guttene som nå er blitt ungdommer, sitter på ungdomsanstalt og folkekravet lyder at de må overføres til fengsel for fortsatt soning. Monstre er skapt. Samfunnsformen vår legger til rette for slikt. Mobiliteten, at vi ikke kjenner personene annet enn gjennom tabloidpressen virker slik. Den daglige dynking av vold og motvold gjennom televisjon likeså. Overvåkingsteknologien virker i samme retning (Gundhus 2000). Det er en kulturkamp som pågår. Hvordan skal vi få vist oss fram for hverandre så det jeg vil påstå er det vanlige, det menneskelige, kommer til syne?

For meg står dette som det store kriminalpolitiske spørsmål. En stadig utvidelse av området for styring med straff understøtter krigsbildene, understøtter tabloidpressens virkninger, og demper i tilsvarende grad mulighetene for den mangefasetterte presentasjon av medmennesker som hele mennesker. Fordi noen skal straffes, altså stigmatiseres og påføres pine, må man av rettssikkerhetsgrunner se bort fra det meste, i personene og i situasjonene. Forbryteren er som skapt for tabloidpressen. Partene i en meglings- eller gjenopprettelsesprosess er høyst uegnet. Hvis det er en god prosess, får vi vite så mye om de sentrale aktører at det krever en romanforfatters talent for å gjenfortelle hvem de er og hvorfor de handlet som de gjorde. Ved slike forhandlinger er det ikke klare kriterier for relevans, deltakerne bestemmer relevansen av de momenter som kan tas med.

Jeg lyttet for en tid siden til dommer Sinclair. Han var en stor, kraftig kanadier av indiansk herkomst. Han ledet sirkelprosesser nord i Canada. Alle med interesser i saken deltok. Og alle på stedet hadde interesser i saken. Så salen var full. De satt i store sirkler, og så gikk en hvit fjær rundt fra person til person. Den som hadde fjæren, hadde talerett, men behøvde ikke si noe. Denne gang gjaldt det en ungdom som hadde drept. Mange sa noe. Fortalte om sider ved den som hadde gjort noe galt, beskrev hans fortid, noe fint, noe så galt så galt. Fjæren gikk langsomt rundt. Ingen fant på å avskjære. Det som tar tid, må få sin tid, sa dommer Sinclair. Det ble en prosess hvor verdigrunnlaget ble repetert og innskjerpet, og det på en meget tydeligere måte enn om gjerningsmannen etter en vanlig prosess hadde fått tildelt $\mathrm{x}$-års fengsel for å markere at en verdi var krenket. Her endte saken, etter forslag fra noen i sirkelen, med at den som hadde gjort det uakseptable skulle tilbringe ett år alene på en øy utenfor kysten. En gang i uken ville hans onkel ta seg over til øya og se til ham. Ungdommen kom tilbake som en meget habil fangstmann.

Men det er et problem med den mediaskapte opinion. Gerry Johnston (2000) diskuterer dette i aprilnummeret av "Punishment and Society". Artikkelen kaller han "Penal policy making. Elitist, populist or participatory". Tittelen er god. Vi 
har beveget oss fra elitistisk styring av kriminalpolitikken over til populistisk, men har i den prosessen slett ikke fått med den folkelige deltakelse som ligger $\mathrm{i}$ ordet. Kriminalistforeningene er ikke hva de engang var. Spørsmålet blir om vi kan komme videre, komme vekk fra politikeres forenklede bruk av kriminaliteten (Tham 1998) til å skape forestillinger om handlingskraft. Britene eksperimenterer med lokale opinionsundersøkelser som skal rettlede dommerne om folkemeningen. Men som Bourdieu (1993) sier, den offentlige mening finnes ikke, det som kommer fram ved slike undersøkelser er noe som skapes gjennom selve spørremetoden. Vil man vite hva folket mener, må man gå annerledes fram. Man må gi den man spør et maksimum av kunnskaper om hva saken gjelder, og dessuten ansvar for konsekvensene av det de svarer. Opinionsundersøkelser gir den uinformerte populisme fritt spillerom. Skal vi videre må vi gå til de siste ord i Johnstons artikkel - participatory policy making. Og da kommer vi tilbake til hva folk i strafferettspleien ofte får erfare: Hvis legfolk kommer i naerkontakt med tiltalte, så blir ikke denne sa mye av en forbryter som et medmenneske. Da skapes muligheter for å møte ham som folk flest. "Riktignok bør det straffes strengt, men forholdene i "min" sak var så helt spesielle", lyder av og til begrunnelsen for de plutselige anfall av mildhet. Utfordringen ligger i å slippe vanlige mennesker løs på de uønskede hendelser, ta fatt i dem, protestere, men også å finne løsninger, spontant eller i ordnede forhold i konfliktråd, andre sivile organ eller eventuelt ved domstolsmegling.

\section{En plass for straff?}

Vil jeg da avskaffe straffedomstolene fullstendig?

Nei. Fire hensyn blir for meg avgjørende.

Det gjelder for det første hensynet til dem som ikke vil delta i en prosess av gjenopprettelse, eventuelt forsoning. Noen gjerningspersoner vil ikke orke eller våge å se offeret $\mathrm{i}$ øynene, langt mindre be om tilgivelse, de vil foretrekke den upersonlige rettssak. Noen offer vil heller ikke høre snakk om forsoning, de vil se gjerningspersonen straffet. I begge tilfelle vil strafferettsapparatet tre i aksjon. Den sivile konfliktløsning kan vanskelig tenkes i en moderne stat uten den strafferettslige løsning som et tilgjengelig alternativ.

Et annet hovedhensyn er at forsoningsprosesser kan utarte. Den som gjorde det gale, eller hans nærstående, kan i fortvilelse love for mye for å gjøre det gale godt. Megleren må stoppe dette, og kan derfor bli tvunget til å sende saken tilbake til de vanlige domstoler. Eller offeret kan bli utsatt for alt for sterkt press fra den annen part. Det finnes eksempler fra canadiske småsamfunn hvor mennene dominerer konfliktløsningsorganet og mishandlede kvinner ikke møtes med rett, men med fortsatt undertrykkelse.

Et tredje hensyn er eksistensen av situasjoner hvor intet konkret offer finnes. Det kan være en idé som krenkes. Noen kan forbanne Gud eller Allah, i stater hvor slik forbannelse gis den mening å være meget syndig. Eller det kan være 
hva mennesker gjør med seg selv og sin kropp man ønsker å regulere. Historien er full av innsats mot antatte skadelige nydelser.

Og så kommer det mer trivielle hensyn at enkle ordensregler i siste instans kan trenge støtte. Noen bilførere vil insistere på å holde den fart de selv finner rimelig. Sivile forholdsregler som inndraging av sertifikat eller bil bør prøves, men vil ikke alltid nytte. Straff må bestå som den siste mulighet.

Mitt personlige standpunkt blir minimalistens. Vi må beholde strafferetten hvor parter ikke finnes, hvor parter ikke kan anerkjenne andre løsninger, og for problem som gjør denne løsning uunngåelig. Men forsiktig og begrenset og hele tiden med maksimale muligheter for sivile gjenopprettende løsninger anvendt av parter som finner at disse løsninger er de beste. Argumentene om at straff må anvendes fordi folket krever det kan ikke gis fortrinn framfor argumentene for at sivile konfliktløsninger må anvendes hvor partene klarer å bli enige om slike løsninger. De beste argumenter taler for at påtalemyndigheten mister sitt monopol over saksutvalget, og at partene i alle saker hvor parter finnes får rett til å forsøke å finne fram til sivile løsninger.

\section{Statens tarv}

Men kunne en moderne stat finne seg i dette? Om noe forferdelig var skjedd med offeret, men dette vendte det annet kinn til, og tilgav gjerningspersonen? Og om det nå var klart at tilgivelsen var ekte, offeret mente dypt og oppriktig, uten noensomhelst tvang eller utenforliggende hensyn at gjerningspersonen skulle tilgis. Og la oss også anta at det var klart at gjerningspersonen - også dypt og ekte - erkjente å ha handlet galt. Verdiens gyldighet var gjenopprettet. I slike tilfeller: Kunne staten sitte rolig og bare la tilgivelsen skje?

Den gjør det nå, i småsaker. Det er derfor vi kan ha en ordning med konfliktråd. Men kunne den gjøre det $\mathrm{i}$ de store?

Det er særlig tre hensyn som taler mot en slik løsning.

Det første springer ut av særtrekkene ved vår samfunnsform. Landsbyen kan gjenopprette en skadet verdi ved at alle ser hva som skjer. Per har skadet Kari, men Per gjør det godt igjen. Alle er med, i det minste gjennom jungeltelegrafen den neste dag, og det vil bli viden kjent hvorledes Per gråt over det onde han hadde brakt over Kari, hvordan han gav henne noe av det fineste han eide, og så, om alt det gode som skjedde under forsoningsmiddagen som fulgte. Vi har ikke i vår samfunnstype de samme muligheter for å gjøre forsoningen kjent.

Noe av svaret på denne innvending ivaretas imidlertid ved den utvikling som skjer i konfliktrådene i Canada, New Zealand og Australia. Tendensen går sterkt i retning av å utvide sirkelen av dem som er med. I Norge er vanligvis bare med de to hoveddeltakere i konflikten, og så en megler. Det skjer i privatiserte former. I disse andre land kan storsalen være full av slekt, venner og bekjente på begge sider i konflikten. Det bidrar til at alt trekkes fram. Det bidrar til at parter modererer seg, - og det bidrar til at informasjonene spres om hva som var 
skjedd, og om hva det førte til. Det blir deltakende konfliktbearbeiding, og da deltakelse i meget vid betydning. Mon tro om ikke grunnfjellet i våre verdier ivaretas bedre ved at hundrevis av slike møter finner sted over det ganske land, enn om de rutinemessige straffesaker kjøres gjennom på vanlig vis.

Men så kommer det annet mothensyn: Dette vil jo bety rettsulikhet. Det blir ulikhet fra sted til sted. Kanskje Per må gi både bil og tårer i indre Sogn, mot bare tårer på Hamar. Ja vel, kanskje så de forskjellig på hva han hadde gjort de to steder, og om det ikke var straff, men gjenopprettelse, måtte det vel være akseptabelt at disse forskjellene kom til syne i sluttresultatet. En annen type rettsulikhet er kanskje vel så viktig: Noen gjerningspersoner vil ikke orke eller våge å se offeret $\mathrm{i}$ øynene, langt mindre be om tilgivelse, de vil foretrekke den upersonlige rettssak. Noen offer vil heller ikke høre snakk om forsoning, de vil se gjerningspersonen straffet. I begge tilfelle vil strafferettsapparatet tre i aksjon. Den sivile konfliktløsning kan vanskelig tenkes i en moderne stat uten den strafferettslige løsning som et tilgjengelig alternativ. Dette betyr at den ene person møtes med tilgivelse i sivile former, mens den annen straffes. Men på ny, det strider neppe mot etikkens grunnlov at noen, men ikke alle, møtes med tilgivelse. De straffede møtes med det de ville blitt møtt med om forsoning ikke fantes. Men det straffes ikke mer, og kanskje blir det til og med etter hvert mindre. Hvis tilgivelsen kommer inn som et aktuelt alternativ i noen tilfelle, vil det trolig få mildnende virkninger også for den alminnelige straffeutmåling.

Det tredje hensyn gjelder statens autoritet. Herskere viser alltid stor aktivitet for å få herredømme over straffen, det er et godt område for maktmanifestasjoner. Våre statsdannelse er svekket ved å ha mistet styringen over finansverdenen. Mister den straffen, mister den mye. Det ligger et paradoks her. For å tekkes de velstående fristes staten inn i prosjekter av typen zero-tolerance. Der bør den ikke være. Men om straffen ble fullstendig avskaffet, mistet staten ytterligere styringsautoritet på områder hvor den kanskje burde fă beholdt autoriteten.

Disse tre hensyn er viktige, og i forhold til et abolisjonistisk standpunkt for meg avgjørende. Men som vi har sett, vil ikke staten miste det hele. Noen vil slett ikke tilgi. Andre saker har intet spesifiserbart offer. Staten blir ikke arbeidsløs på strafferettens område. Det saken gjelder, er å hindre mega-vekst innen den straffende sektor, ikke avskaffelse av det hele.

\section{Kriminalpolitikk er kulturpolitikk}

Den store kriminalpolitiske utfordring i dag er ikke å skjerpe straffene eller styrke straffeapparatet, men å skape en rimelig balanse mellom den sivile og den strafferettslige sektor. Da jeg begynte i mitt fag hadde vi her i landet 30000 anmeldte forbrytelser per år. Nå har vi nesten 300 000. Utfordringen ligger i å bevare den sivile sektor av samfunnet. Vi kan ikke fortsette hva Hans Henrik Brydensholt (1994) kaller den lineære utvikling, - hvor vi hele tiden bare får mer av det samme. Vi kan ikke la strafferettsvesenet ordne opp i stadig mer uten 
i betenkelig grad å bevege oss i retning av russiske eller USA-tilstander i Norden. Intet samfunn tåler at intet skjer om viktige verdier krenkes. Uakseptable handlinger må det reageres mot. Men straffen har ingen selvfølgelig prioritet som reaksjonsmiddel Det er et kulturspørsmål. Viktige verdier står mot hverandre. Slik sett tror jeg nokså mange vil kunne slutte seg til det syn at saker som kan få sivile løsninger bør få slike løsninger.

Hvor langt vil jeg da gå?

Jeg mener en viktig opgave nå venter på Riksadvokatens initiativ.

Riksadvokaten må utvide sitt nåværende rundskriv om hvilke saker som kan oversendes til konfliktråd. Konfliktrådsordningen er i rivende utvikling i en rekke industriland. Norge var engang i spissen. Det er flaut i dag å komme til land som New Zealand, Canada, eller Belgia og fortelle hvor langt vi nå henger etter i Norge. Saker som kvalifiserer til ubetinget fengsel kan ikke avgjøres med konfliktsrådsbehandling sier Riksadvokaten i sitt rundskriv av 6. desember 1993. Senere har vi fătt en ny Riksadvokat. Vi venter nå på et nytt rundskriv, ett som radikalt utvider rammen for saker som kan gis sivile løsninger.

Påtalemyndigheten er tradisjonelt meget opptatt av hensynet til forebyggelse. Utmerket. Her venter en sentral forebyggende oppgave. Påtalemyndigheten må gjøre sitt ytterste for å forebygge en ytterligere svekkelse av den sivile sektor i vårt samfunn. Det gjør den ved å sette grenser for veksten av den strafferettslige sektor.

\section{LITTERATUR}

Bauman , Zygmunt 2000 "Social Issues of Law and Order". British Journal of Criminology, 40, s. 205-221.

Bourdieu, Pierre (1998) Om televisionen. Brutus Østlings Bokførlag.

Brydensholt, Hans Henrik (1994) Alternativ konfliktløsning. Festskrift til Børge Dahl.

Dullum, Jane (1996) Konfliktrådene. Institutt for kriminologi, Oslo.

Estrada, Felipe (1999) Ungdomsbrottslighet som samhällsproblem. Kriminologiska Institutionen, Stockholm.

Gundhus, Helene (2000) Nye kontrollmetoders virkninger på forståelsen av avvikende handlinger. Innlegg på Forskningskonferansen, Nordisk Samarbeidsråd for Kriminologi, Bergen, mai 2000.

Johnstone, Gerray (2000) "Penal policy making. Elitist, populist or participatory". Punishment and Society, 2, s. 161-180.

Scheerer, Sebastian (utgivelse 2001) "Kritik der strafenden Vernuft". Ethik und Sozialwissenschaften. Streitforum für Erwägungskultur. Heft 1. Manuskript.

Slagstad, Rune (1998) De nasjonale strateger. Pax, Oslo.

Tham, Henrik (1955) "Från behandling til straffvärde - Kriminalpolitik i en förändrad välfärdsstat", Varning för straff. Om vådan av den nyttige straffrätten. Red: Dag Victor.

Adresse: Institutt for kriminologi

Postboks 6872, St. Olavs Plads

N-0130 Oslo

E-mail: nils.christie@jus.uio.no 